\title{
West Indian literature and Federation: imaginative accord and uneven realities
}

In as much as late nineteenth-century Antillean Confederation and mid twentieth-century West Indian Federation grew from the same impulse towards acts of political reimagining, they shared a creative rearrangement of the conception of the Caribbean world at their center. This shaping of new narratives for the political future of Caribbean places was the foundational work of both movements, with their distinctive but related ideas of reconstructing societies released from the hold of Empire and rooted in regional fellowship. For the passionate advocates of both forms of this "adventurous enterprise," a capacity to imagine ideas of governance, citizenship, and autonomy that brought the peoples of Caribbean territories together to contest and undo the exploitative web of Empire was crucial. It is likely on account of this necessity for re-imagination that political and literary visions converge in so many of the canonical writings that look to engage with and explain the project of West Indian Federation in the 1950s. Indeed, despite the assertion of Gordon Lewis that the underpinnings for federation lay in the rather prosaic yet "remarkable growth of the commercial airliner in the last few decades, "2 closer reading of those works seeking to articulate and affirm federation suggests that the flight of the literary imagination also played a significant role in crafting the connections between peoples and places that allowed for the modeling of a West Indian sensibility.

In his June 1958 speech at Queen's College to a Guyanese audience somewhat rattled and divided at the prospect of federation, C. L. R. James concludes with a discussion of two Trinidadian writers: Samuel Selvon and V. S. Naipaul. After presenting his lengthy and compelling argument for federation as an indispensable means to economic and political

\footnotetext{
${ }^{1}$ Gordon Lewis, "The British Caribbean Federation: the West Indian Background," The Political Quarterly 28, no. 1 (1957): 49-63, 50.

${ }^{2}$ Lewis, "The British Caribbean Federation," 50.
} 
reorganization across the decolonizing Anglophone Caribbean region, James turns to the power of literary culture to represent and rearticulate West Indian identities and lives. Raising the stakes of imaginative writing as a transformational tool for collective self-realization, James frames the commitment to federation as an obligation to the region's writers:

Are we going to close ourselves in narrow compartments, whereby we shall be limiting our writers and our artists to the free expression of only one aspect of our community? Writers, and artists of all kinds, are of particular importance at this transitional stage of our development. They interpret us to ourselves and interpret us to the world abroad which is anxious to know about us. These highly gifted people are able in a few thousand words to illuminate aspects of our social and personal lives which otherwise would have taken us years and great pain and trouble to find out. We have to give them all the help we can, create the conditions in which they can best perform their work for our society. Above all we must beware of limiting them in any way. In doing so we limit ourselves. ${ }^{3}$

Driven by the social, economic, and political conditions across the region, federation was, as James invokes, concerned with building a political community based on the recognition and articulation of a West Indian "us and we," an inclusive decolonial nationalism. As we know, James's story of this community and his sense of the obligation to an expansive literary imagining of the West Indies was not persuasive enough. Guyana did not join the federation and the endeavor "to dwell together in unity" (as the motto described it) was short-lived. ${ }^{4}$ All the same, the privileged role that writers were seen to play in articulating a new consciousness of West Indian realities and identities, and the ways in which literary works

\footnotetext{
${ }^{3}$ C. L. R. James, "Lecture on Federation," in At the Rendezvous of Victory: Selected Writings (London: Allison and Busby, 1984), 105.

4 “West Indies Federation,” En.Wikipedia.Org, 2019, https://en.wikipedia.org/wiki/West Indies_Federation. [Accessed 20 June 2019].
} 
were both actively cherished and passively presumed to be the touchstone of an aesthetics of federation, remains a significant and compelling feature of the way in which federation shaped its call for political reimagination.

My interest here is to explore the wider articulations of the "particular importance" conferred on writers in terms of their place in the people-building project of the West Indies and the specific movement towards federation. However, as well as exploring the distinctive character of the political responsibility accorded to literature in the context of West Indian Federation, this essay also discusses the constraints on writers and literary projects in terms of inhabiting the collective decolonised belonging that they were tasked to imagine into being. While the primacy given to writing established a clear expectation around West Indian literature as an innately federal form, ironically this writing was often accomplished in a metropolitan elsewhere because the material realities facing the writers themselves curtailed their own possibilities for a regional belonging as professional authors.

The movement towards federation coincided, of course, with the boom of West Indian literature. In the same year that federation was achieved, the formative Caribbean Voices BBC Radio Programme came to an end after successfully broadcasting West Indian literary voices into West Indian households for over a decade (a topic discussed in more detail by Glyne Griffith's essay in this special section). The close-knit association between Caribbean writers in the Anglophone region and the project of imagining and crafting decolonized subjects with a sense of local belonging and the will, and indeed capacity, for autonomy, is well known. Starting in the early twentieth century and gaining momentum and political edge from the 1930s onwards, both individual writers and the little magazine projects that emerged locally to publish them were central to the project of making West Indian literature visible and meaningful. Yet, in some ways, it is precisely this ready anticipation of the shared objectives and trajectories of West Indian literature and federation as cultural projects that 
makes the nature their contiguity difficult to ascertain. One obvious observation is that even after "federal morale deteriorated" (to use Bernard Marshall's phrase) $)^{5}$ West Indian literature went on to thrive. Indeed, in his 1988 article, "West Indian Literary History: Literariness, Orality, and Periodization," Kenneth Ramchand makes a claim for West Indian literature as one of only three institutions that embodied and sustained the "federal idea" after the breakdown of federation itself:

When the English-speaking territories formed themselves into a political federation in 1959, the name chosen for the nation-to-be was "The West Indies." The federation broke up almost at once, but the name has remained to signal a reality stronger than any political institution. Three cultural institutions exist to keep alive the federal idea: the University of the West Indies, the all-conquering West Indian cricket team, and West Indian literature. ${ }^{6}$

Just as C. L. R. James's speech draws on writers and their expansive imaginations to deliver the crescendo to his call for political unity, thereby implicitly positioning creative writings from the region as exemplary in their West Indian character and sensibility, Ramchand similarly argues for an aesthetics of federation that exceeds the limited purchase of the political project.

For Ramchand, as for James, literature is clearly a privileged vehicle for imagining and sustaining regional unity:

When independence came it came almost as an anti-climax out of the demise of the West Indian Federation. There was no struggle for independence by individual islands. All the talk had been about "being a West Indian," "West Indian culture," and

\footnotetext{
${ }^{5}$ Bernard Marshall, “Attempts at Windward/Leeward Federation," Caribbean Quarterly 18, no. 2 (1972): 9-15, 15.

${ }^{6}$ Kenneth Ramchand, "West Indian Literary History: Literariness, Orality and Periodization," Callaloo, no. 34 (Winter 1988): 95-110, 95; emphasis mine.
} 
impacting on the world as a united West Indian nation. The literature of the 1950s and 1960s was of West Indian inspiration. ${ }^{7}$

Certainly, for some Caribbean-based writers working at this moment, a federated future was the political horizon towards which they enthusiastically imagined. As Katerina Gonzalez Seligmann has noted in her research on BIM (a Barbadian little magazine project of this period that published the work of both emerging and more established writers from across the Anglophone region) recognizing and gathering literary works by a range of writers from across the region accrued symbolic capital in terms of new political commitments:

On June 11, 1949, in a letter to Frank Collymore, George Lamming exclaimed that West Indian literature was "REALLY TAKING SHAPE!” As Lamming continued, And I was dreaming of the day when $B I M$, by another name, would become a West Indian monthly with a paid editor, and whether you could attempt it after your resignation which, let us hope, isn't too far ... It seems to me that the editor of such a magazine through the organ itself does more for this community than all of the politicians put together (George Lamming Letters to Frank Collymore, 1946-1950)

Lamming's dream did not altogether come true, for Collymore never became the paid editor of a monthly magazine. But this moment of hopeful engagement with BIM is crucial in his series of letters to Collymore. It demonstrates his prescient understanding that West Indian literary production and literary culture were becoming observable realities and that $B I M$ was integral to their prior, present, and future evolution. ${ }^{8}$

\footnotetext{
${ }^{7}$ Ramchand, "West Indian Literary History," 98.

${ }^{8}$ Katerina Gonzales Seligmann, Unpublished manuscript (2019)
} 
While we might expect James and Lamming, both writers, and Ramchand, a literary critic, to highlight the relevance of West Indian literature in shaping a West Indian consciousness that could inspire and fortify the aspirations of federation in its ambitious act of political community-building, literature's formative presence is more striking in the work of renowned intellectuals Gordon Lewis and David Lowenthal. Lewis's 1957 essay “The British Caribbean Federation: the West Indian Background" is a careful and measured study of the promise of federation and of the obstacles yet to be overcome. Cautiously optimistic about the possibilities for social and political transformation implied by the "path of international cooperation," at his most celebratory moments Lewis invokes expressive cultural forms through which "a new sense of pride in the local tradition, in the hitherto repressed African heritage" can be achieved, including the work of writers George Lamming and Edgar Mittelholzer. ${ }^{9}$ Indeed, more notable still with regards to the confidence placed in writers to offer an imaginative foothold into a federated consciousness is the way in which Lewis's own writing shifts from the conditional tense of modest anticipation into the present tense of realization when he discusses literary works. In this way Lewis's essay not only acknowledges the role of writers but also divulges his sense that writers provide a privileged, symbolic glimpse of a West Indian sensibility that it is hoped federation will achieve and embed as a material reality.

This distinctive recognition of, and investment in, the literary as the form most able to articulate a West Indian sensibility also surfaces in David Lowenthal's edited collection The West Indies Federation: Perspectives on a New Nation, which comprises four chapters on "problems \& prospects"; "survival of the past"; "political development"; and "social background." In the latter, his own contribution to the volume, Lowenthal deals mostly_at his own admission — "with features that seem to divide West Indian loyalities, and to show

\footnotetext{
${ }^{9}$ Lewis, "The British Caribbean Federation," 65, 64.
} 
that the federated islanders are something other than West Indians, or are dissatisfied with being West Indian." 10 It is only on the final page and a half that Lowenthal turns to the "ferment of self-discovery" and the particular promise that the West Indies—as a collective of societies with similar histories, demographics, and cultural multiplicities — holds "to teach the world that despite a heritage of slavery, colonialism, and poverty, a people of varied ethnic backgrounds and social ideas can achieve not only comfortable coexistence but nationhood and personality." ${ }^{11}$ Significantly, for his closing peak of optimism, Lowenthal, like James, invokes V. S. Naipaul who had by then only published his affectionately West Indian writings: The Mystic Masseur (1957); The Suffrage of Elvira (1958); Miguel Street (1959); and A House for Mr Biswas (1961).

Lowenthal's collection makes no other mention of West Indian literature in the essays that comprise the main body of this collection, but the bibliography for the volume is divided into six parts: 1) Government Reports; 2) Physical Geography; 3) History; 4) Contemporary Affairs; 5) Belles-lettres; and 6) Periodicals and newspapers. Giving the title of "Belleslettres" to the works of West Indian writers published between 1952-1960 ostensibly suggests that Lowenthal regards these works as more valuable for their artistic pleasure than intellectual weight. Yet, in the absence of any interpretative gesture, the simple but highly suggestive act of including a bibliography of West Indian literary works in a volume focused on socio-political perspectives again demonstrates the privileged significance accorder to writers and a regional literary aesthetic in terms of anticipating and even mapping the grounds for political unity in their imagining of a confederated Caribbean space.

Among the literary works that Lowenthal lists are the two anthologies dedicated to federation. The first, A. J. Seymour's 1957 Anthology of West Indian Poetry (Kyk-Over-Al

\footnotetext{
${ }^{10}$ David Lowenthal, The West Indies Federation: Perspectives on a New Nation (New York: Columbia University Press, 1961), 95.

${ }^{11}$ Lowenthal, The West Indies Federation, 95, 96.
} 
22), is not overtly tagged by Lowenthal as a federation anthology and, indeed, is rather strangely fashioned as such. A lightly revised edition of The Kyk-Over-Al Anthology of West Indian Poetry, originally published in 1952, Seymour adds a charming and surprisingly succinct addition to the preface in which he states: "The voices are surer and I have changed some of the songs; the federation is a reality and nationhood is gathering rapidly. The order is now alphabetical."12 The unremarkable tone and casual phrasing of Seymour's remarks are most noteworthy here. The very lack of an explanatory narrative for how the poetry selected and the sensibility of West Indian unity cohere intimates that in Seymour's eyes the earlier anthology (and the work of writers included therein) had already constituted an imaginative federation alongside which the political alliance had now, at last, managed to successfully align itself_-"the Federation is a reality."

This conjecture is further established by the sentiment Seymour expresses in his preface to the original anthology where he outlines the confederated aesthetics integral to his assemblage of writers from across the region, "the purpose of the anthology would be to introduce the poets of the region to the people of the British Caribbean" in order to promote an appreciation wider than the nation: "It is for pleasure that these poems have primarily been chosen, but there is also the possibility that a collection of this kind may express the spiritual and intellectual identity of the West Indies and may help us to win the feeling of being spiritually at home in these imaginative writings which have their birth in the peculiar conditions of our West Indian people."13 Here, Seymour, like C. L. R. James in his later speech, draws attention to the particular significance of writers and artists in the project of building inclusive imagined communities: "In any community, the poet shares with the

\footnotetext{
12 A. J. Seymour, ed., Anthology of West Indian Poetry (1957, repr., Guyana: Kyk-Over-Al, 1952), xi.

${ }^{13}$ A. J. Seymour, ed., The Kyk-Over-Al Anthology of West Indian Poetry (Guyana: KykOver-Al, 1952), xi.
} 
painter and the musician (and in a degree greater than they, in a young community where he has an importance he has lost in older societies) the task of supplying an imaginative record of the experiences which all the members undergo."14

In the issue of Caribbean Quarterly that Lowenthal lists, content is far more explicitly styled to commemorate federation. Also a poetry anthology, with many names overlapping from the $K y k$ gathering, this collection appears to be a conscious collaboration between the Anglophone region's little magazines and their editors: Frank Collymore from BIM, published in Barbados but with a regionally-inclusive agenda, A. J. Seymour from Guyana's similarly open periodical Kyk-Over-Al, and also Edna Manley and her Jamaican publication Focus. This editorial alliance is itself a significant gesture towards the bridging of cultural nationalism and regionalism prominent in the rubric of federation. Philip M. Sherlock's editorial to the issue is brief — less than one full page — and its mission is conveyed in a single opening sentence: "Let the artists, the poets, and the writers speak of the flaming directions that live in us today." 15 In this instance too, the dearth of any explicit statement or discussion relating these literary works to the project of federation seems to indicate an assured proximity, and the innate readiness of the region's creative voices to announce a federation aesthetic. Sherlock quotes from Barbadian Hugh Worrell Springer, then Registrar of the University College of the West Indies and a strong advocate for regional integration, on the sense of an epochal shift in which "the majority, with increasing self-confidence, have begun to find merit in their own way of life, recognisably West Indian."16 The actual poetry gathered in these two volumes has no manifest framing or content that speaks to crossregional perspectives or a particular focus on unity. Rather, it is as if a gathering of poets

\footnotetext{
${ }^{14}$ Seymour, The Kyk-Over-Al Anthology, x.

${ }^{15}$ Philip M. Sherlock, "Editorial," Caribbean Quarterly 5, no. 3 (1958): 121.

${ }^{16}$ Sherlock, "Editorial," 121.
} 
from across the Anglophone region was inevitably, tacitly, an expression of and conviction in West Indianness.

Both the stated and unstated expectations that literary writings were integrally part of the regionalizing project seem to have projected an aesthetics of federation to which political commitments must look to do justice (as C. L. R. James argues) or against which political gestures can only pale in comparison (as in Ramchand and Lamming's views). As a literary historian what strikes me is that West Indian literature may not have been quite the fully realized federal project which those advocating for political federation imagined and wanted it to be in order to meet their demands for inspiration. Rather, both projects shared the challenges of seeking to negotiate a West Indianness shaped by tensions between commitments to local, regional, and global circuits of value that operated as the warp and weft of a single fabric. In terms of West Indian literature and its dedicated re-imagining of local lives and identities, Kezia Page has persuasively argued for an intricate "in-betweenity" that characterized writers of the 1950 s as much as later generations who are more readily understood as diasporic and multi-locational. ${ }^{17}$ Page notes "their attempt to speak directly to a Caribbean regional audience and to position their work as a form of cultural remittance ... to be authenticated in the region, while seeking to 'plant' by infiltration a Caribbean diaspora on foreign/imperial soil." ${ }^{18}$ It is this more unstable and evolving status of West Indian literary sensibilities that emerges in a publication which Lowenthal does not list but which arguably addresses most clearly the contradictions and complications of the relationship between West Indian writings, and writers, and the call and promise of federation.

A special issue of the Tamarack Review, a Canadian literary journal, published in Winter 1960 under the title of "The West Indies," mainly comprised extracts of work already

\footnotetext{
${ }^{17}$ Kezia Page, Transnational Negotiations in Caribbean Diasporic Literature: Remitting the Text (London: Routledge, 2011), 15.

${ }^{18}$ Page, Transnational Negotiations, 10.
} 
published in the region or in the UK, including some extracts from the same 1952/57 KykOver-Al anthology. This volume featured work from what would soon become, from other anthologizing projects, an increasingly recognizable canon of West Indian writers: Martin Carter, Frank Collymore, John Hearne, Cecil Herbert, George Lamming, Edgar Mittleholzer, Victor Reid, Eric Roach, Samuel Selvon, Philip Sherlock, and Derek Walcott. Victor Reid's opening essay "The West Indies: A New Nation" provides an eloquent account of the centuries of colonial misrule characterized by inter-island strife that led up to federation as well as a candid description of the Crown/colonial involvement in the federal project. Unambiguously focused on educating a Canadian audience on West Indian history, Reid's essay does not make an argument in favor of federation but rather (like Lowenthal) emphasizes the threats it faced. Although in Canada on a writing fellowship sponsored by the Canada Council, the issue of literature is interestingly absent in Reid's account of collective political possibilities for the West Indies. ${ }^{19}$ The story by Sam Selvon that follows, "Come Back to Grenada," is in fact a refusal of the call to return to the Caribbean home and a lyrical depiction of the West Indian life that London now hosts - albeit a life based on the precarious solidarity of shared "old talk" about "home in the West Indies." 20 The extract from George Lamming's The Pleasures of Exile similarly depicts an alternative federation of writers, "the product of a new country," dwelling in the unity of exile and professional authorship despite - he makes it clear - C. L. R. James's injunction to "bring them back." 21 This contradictory location, in the colonial metropolis, of the very West Indian literary sensibility so influential to reimagining the political base for postcolonial belongings cannot be

\footnotetext{
${ }^{19}$ Victor Reid, “The West Indies: A New Nation," Tamarack Review no. 14 (Winter 1960): 6-14.

${ }^{20}$ Sam Selvon, “Come Back to Grenada," Tamarack Review no. 14 (Winter 1960): 15-26, 16.

${ }^{21}$ George Lamming, “The Pleasures of Exile," Tamarack Review no. 14 (Winter 1960): 32$56,32,53$.
} 
overlooked, as Eric Duke also argues in his study of New York and London as influential locations in support of the project of federation. ${ }^{22}$ More in tune with the volume's dedication to writing and the region, the poems by Roach, Sherlock, Carter, and Walcott (significantly writers who all remained in the region) included here might be seen collectively to express a poetics of the West Indies and West Indians. There is nothing to declare individual works as overtly regionalist. Indeed Roach's 'Homestead' appears here rather than his "Fugue for Federation” (1958). All the same, 'Homestead,' with its central figure of the poet as a celebrant of the unrecorded Caribbean labouring man, an ancestor of those enslaved who now possesses the eye of the landscape, both enacts and enables a localized literacy. By this, I a practice of reading the region in its own terms and an aesthetic of shared experience that those summoning the spirit of political federation seemed most cherish to within the literary. A far more politically charged sense of the poet's responsibility to recount Caribbean realities as worldly realities informs Martin Carter's 'Two Poems' collected here: 'Words' and 'Voices.' In Words the poet's duty to declaim the realities of unseen Caribbean lives is an obligation to unlock a language of historical and psychic violence that is a global injury: 'These poet words, nuggets no jeweller sells/across the counter of the world's confusion/ but far and near, internal and external/ burning the agony of earth's complaint. ${ }^{, 23}$ Certainly, Walcott's one act play, The Sea at Dauphin, about two fishermen caught between the pulls towards the sea (regionalism) and the land (nationalism), also included in this special issue, is taken by Michael Malouf to be "one of the first successful attempts at a regional theater in its use of St Lucian French-English patois as a dramatic style... [that] has been recognized as

\footnotetext{
${ }^{22}$ Eric Duke, Building a Nation: Caribbean Federation in the Black Diaspora (Gainsville: University Press of Florida, 2016).

${ }^{23}$ Martin Carter, "Words" Tamarack Review no. 14 (Winter 1960): 57.
} 
integral to the formation of a West Indian aesthetic". ${ }^{24}$ In its composition, this special issue of Tamarack Review present the complicated and overlapping vectors of cultural attachment, imagined co-belongings and diasporic lives as a common condition of West Indianness - an identity in which fractures and unities are continually held in tension.

The aesthetic cohesion summoned to exalt West Indian literature as a beacon of federation may have brought into imagination the "flaming directions" of cultural sovereignty that Philip M. Sherlock described and have given value to the federation idea/l of "dwelling together in unity." ${ }^{25}$ However, the male migrant writers associated with the formation of West Indian literature (and who most frequently featured in and commented on the nexus of federation and literary formation) were also deeply embroiled in the discordant realities of economic markets and measures, and the tensions between national and international belongings. Indeed, the contradictory currents of this volume's West Indianness are also exemplified by its publication in Canada, which the distinguished critic and writer Edward Baugh remembers as an importantly validating context: "I still have my copy of the Review. It represented the first substantial recognition of West Indian literature in a big, First World country other than Great Britain."26 This collection thereby captures both the way in which federation had to be imagined before it could be lived and also addresses some of the material and political obstacles that could not transcend the collective imaginary fostered by expressive cultural forms. As Frank Collymore argued in his survey essay of West Indian writing across the twentieth century included in the issue, West Indian writers were simply unable to sustain their careers in the region: "Until their resources are developed and a larger

\footnotetext{
${ }^{24}$ Michael Malouf, 'Dissimilation and Federation: Irish and Caribbean Modernisms in Derek Walcott's The Sea at Dauphin', Comparative American Studies: An International Journal (2010) 8:2, 140-154, 146.

${ }^{25}$ Sherlock, "Preface," 121.

${ }^{26}$ Edward Baugh, "Epilogue: Coming of Age in the Fifties," in J. Dillon Brown and Leah Reade Rosenberg, eds., Beyond Windrush Rethinking Postwar Anglophone Caribbean Literature (Jackson: University Press of Mississippi, 2015), 247.
} 
leisured class interested in the arts emerges, the dedicated writer or artists must seek a living abroad." ${ }^{27}$ The unstated implication in curating these writings is that federation may have created the regional conditions to which the writer could return.

Reading across the range of published works that sought to promote the promise and reward of regional unity it is evident that West Indian literature played a vital role in establishing an aesthetic of federation, even though the writers themselves were often located in contexts outside the region in their pursuit of professional authorship. Indeed, while federation looked to West Indian literature to give authority to its collective vision, West Indian literature looked to federation to create the conditions in which writers might reside in and write for the region whose people-making aspirations they so meaningfully described.

${ }^{27}$ Frank Collymore, "Writing in the West Indies: A Survey" Tamarack Review no. 14 (Winter 1960): 111-123, 123. 